\title{
DRAMATURGY: RIBA ON HOME OWNERSHIP LOAN IN ISLAMIC BANKING (CASE STUDY ON BANK BTN SYARIAH KCPS CIPUTAT, TANGERANG SELATAN)
}

\author{
Aulia Julian Faizatunazilla, Siti Jamilah \\ Islamic Economics, Faculty of Economic and Business, University of Muhammadiyah Jakarta \\ Jl. KH. Ahmad Dahlan Ciputat Cirendeu Ciputat Timur, 15419 \\ E-Mail:auliajulian7@gmail.com jamilah.febumj@gmail.com
}

\begin{abstract}
The purpose of this study was to determine usury behavior in the Housing Loan or Credit in Islamic banks and to determine the application of the existing contract system in Housing Loans in Islamic banks using the dramaturgy method. The data used in this study is primary data, where researchers conducted interviews directly with the Bank BTN Syariah KCPS Ciputat, a member of the Sharia Supervisory Board and one of the customers who used a House Ownership Credit product at an Islamic bank. The results of this study can be concluded that the front stage that the bank shows to the public is in accordance with the back stage that the bank does not show to the public and Bank BTN Syariah KCPS Ciputat conducts its business in accordance with Islamic law and the fatwa of the National Sharia Council. So that in this study Bank BTN Syariah KCPS Ciputat does not have usury in its business.
\end{abstract}

Keywords: Home Ownership Loan, Riba, Dramaturgy

\section{INTRODUCTION}

Home Ownership Loan (KPR) basically has a system in accordance with Islamic law but some people feel that there are irregularities with the Home Ownership Loans (KPR) system such as, first the murabahah contract where the murabahah contract of Islamic banks cannot buy a house because the bank is not a real sector, but In practice, Islamic banks buy the house.

Second, in the sharia rules, if the goods are sold on credit, officially become the property of the buyer even though they have just paid the down payment, but in the Home Ownership Loan (KPR) in a Islamic bank must pay all the agreed costs until it is paid off then the house can be fully owned by the customer.

Third, there is a problem with the concept of sharia because the money used to pay off the purchase of a house is a debt (loan) from the bank, the customer is obliged to pay installments that exceed the bank loan, and if the Islamic bank considers that he has bought the house, then in the bank's Home Ownership Loan (KPR) system sharia implementation, the bank 
violates the prohibition on selling goods that they have not fully received.

Fourth, some people still think that Islamic banks still contain usury. This is because if the payment on the Home Owner's Credit in total the result will be higher than the Ownership Credit in conventional banks.

\section{Research Purpose}

Based on the research formulation that the researchers got, there are several objectives of the research problem, namely to determine the behavior of usury in mortgages in Islamic Banks and to find out the implementation of the KPR contract system in Islamic Banks is in accordance with Islamic law.

\section{Dramaturgy}

The dramaturgy theory put forward by Erving Goffman has two essences, namely:

\section{a. Front Stage}

When humans interact with other people, it will provide an assessment of that person, based on instructions given by others to us or vice versa.

b. Back Stage

According to Erving Goffman, the back stage is a person who performs something and can take a break from all the equipment he uses when presenting himself.

The purpose of Goffman's inner presentation is what the audience will accept from his manipulation. If an actor is successful in playing his role, the audience will see the actor in accordance with the angle that the actor wants to show.

Riba literally means additional, growing or enlarging. While the definition of usury which is widely used in the Islamic economic literature formulated by Imam
Sarakhsi in Mabsut juz XII, page 109 is as follows:

"Riba is the addition that is implied in business transactions without any funding (iwad) that is justified by the sharia for the addition".

Riba is a form of transaction that is prohibited in Islam and is in direct contact with conventional banking practices..

In Surah Al-Baqarah verse 275 explains that:

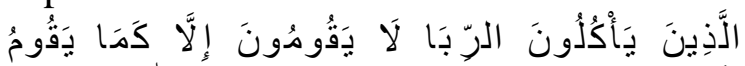

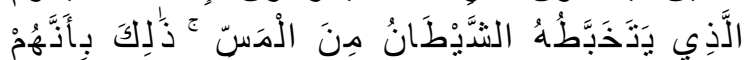

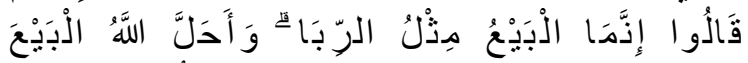

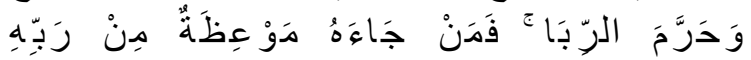

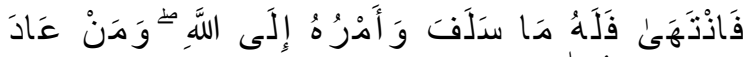

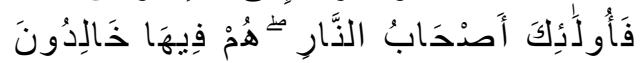

Meaning: "People who eat (take) usury cannot stand, but rather like a person who is possessed by shit because of (pressure) insane. Their condition is like that, is because they say (think), in fact buying and selling is the same as usury, even though Allah has made buying and selling legal and forbidden usury. People who have come to him the prohibition of his Lord, then continue to stop (from taking usury), then for him what he has taken first (before the prohibition comes); and matters (up to) to Allah. People who return (take usury), then that person is the inhabitants of hell; they are eternal in it. (Surah AlBaqarah 275).

There is a source of law that is used to determine the criteria for usury, namely the hadith of the Prophet Muhammad SAW which was narrated by Ubadah bin Samit which is contained in Abu Daud hadith 3343 and in At Tirmidhi hadith 2819 with the following sound:

"Gold will be paid in gold, silver will be paid in silver, wheat will be paid with wheat, wheat flour will be paid for with wheat flour in the same measure, dates 
will be paid for in equal measure, salt will be paid for in equal measure. If someone has given more or asks for more, he is already related to usury. But it is not forbidden to sell gold for silver and silver for gold of different weight. Payment is made in real time and do not sell if paid late. And it is not forbidden to sell wheat with wheat flour and wheat flour (with wheat) in different sizes, payment is made at that time. If the financing is made later, don't sell it".

Riba in payable transactions is divided into two categories, namely Jahiliyah Riba and Qardh Riba. Jahiliyah usury is usury that arises because of a borrower who is unable to pay his debt at a predetermined time. The increase in debt paid is getting bigger along with the delay in repayment of debt. So, this usury system is also known as multiplying money. Meanwhile, Qardh riba is a debt that is paid from the principal, because the borrower is unable to pay his debt at a predetermined time.

\section{House Ownership Loan}

KPR contained in Islamic banks has a definition, namely financing of home ownership in sharia or in accordance with the orders and teachings of the Islamic religion.

In sharia KPR, there is an agreement for an agreement between the customer and the bank, the contract is intended so that the customer and the bank know the agreement and agreement to carry out the mortgage financing submitted by the customer. There are several contracts in sharia mortgages, namely buying and selling which confirms profit (murabahah), buying and selling with terms and construction (istishna '), lease ending in property (ijarah muntahiya bit tamlik), reduced joint venture with rent (musyarakah mutanaqisah).

There are several advantages that exist in Islamic bank mortgages, namely:

a. Installments are fixed, not depending on interest rates

b. When you want to pay off early payments, consumers will not be subject to penalties or fines like conventional banks

c. Financial planning can be done for the family because the installments are fixed.

\section{Syariah Banking}

Islamic banks are financial institutions whose main business is to provide financing and other services in the traffic payment for money supply, where the operation must be in accordance with the principles of Islamic law. Based on Article 4 of Law Number 21 of 2008 concerning Islamic Banking, it is stated that Islamic Banks are required to carry out the function of collecting and channeling public funds.

Islamic banks can also carry out social functions in the form of a baitulmaal institution, namely, receiving funds originating from zakat, infaq, alms, grants, or other social funds (including fines for customers or ta'zir) and channeling them to zakat management organizations. In addition, Islamic banks can also collect social funds originating from cash waqf and distribute them to the waqf manager (nazhir) according to the wishes of the waqf giver (wakif). 


\section{Research Paradigm}

In this study, researchers will use an interpretive paradigm to reveal the front and back stages that exist in Islamic bank mortgages. The interpretive paradigm is a perspective that rests on the goal of understanding and explaining the social world from the perspective of the actors involved in it.

The Interpretive paradigm can view social reality as something that is not separate from one another, something holistic, full of complex meanings, dynamic and the relationship between symptoms is reciprocal, not causality.

The interpretive paradigm is able to perceive social reality as dynamic, processed and subjectively meaningful. Social reality is nothing but a social construction. Regarding the human position, the interpretive paradigm views humans as being conscious and intentional in acting (intentional human being). Humans are creatures that create the world, give meaning to the world, are not limited by external laws, and are the creators of a series of meanings.

\section{Research Design}

Research design can be interpreted as a structured work plan in terms of the relationships between variables in a comprehensive manner so that the research results can provide answers to research questions. The plan includes the things that the research will do, from making hypotheses and their operational implications to the final analysis (Umar, 2007).

In this study, researchers used the dramaturgy method with an interpretive paradigm where the use of these paradigms and methods is mutually sustainable, namely the aim of revealing the meaning of the KPR usury phenomenon in Islamic Banking in Indonesia which shows many positive sides as the front stage that KPR displays on Islamic banks, but there are sides. negative or the back stage that KPR on Islamic banks is not shown to the public.

\section{Site and Research Unit}

The research site is a place where the researcher takes the actual situation of the object under study to obtain the data or information needed by the researcher. This research site will be conducted at the Sharia State Savings Bank (BTN) in Ciputat, South Tangerang and the Sharia Supervisory Board (DPS) and Islamic bank customers.

It suggests that the unit of analysis is the level of unity of data collected during the next data analysis stage. The unit of analysis in this research is the financing service at Bank BTN Syariah, Sharia SubBranch Office (KCPS) Ciputat - South Tangerang, and then the Sharia Supervisory Board (DPS) and Islamic bank customers (Sekaran, 2009).

\section{Data Source}

In this study, researchers used primary and secondary data where primary data were data obtained by researchers directly from first hand. Techniques that researchers can use to collect primary data include observation, interviews, focused discussion and distributing questionnaires.

Meanwhile, secondary data is data obtained and collected by researchers from various sources that already exist in this position as second hand researchers. Secondary data can be obtained from various sources such as the Central Bureau of Statistics (BPS), books, reports, journals, and others. 


\section{Data Collection Method}

In this study, the data collection methods used by researchers were interviews and documentation.

Defining an interview is an interview where two people meet to exchange information and ideas through question and answer, so that meaning can be constructed in a particular topic (Esterberg, 2002).

Documents are records of events that have passed. Documents can be in the form of writings, drawings or monumental works of a person.

\section{Data Analysis Method}

Qualitative data analysis takes place during the data collection process rather than after data collection is complete. Here are some processes for analyzing data:

1. Prior analysis in the field The analysis was carried out on data from preliminary studies or secondary data that the researcher would use to determine the focus of his research.

2. Analysis when in the field According to Miles and Huberman in the book quantitative, qualitative and $\mathrm{R}$ \& $\mathrm{D}$ research methods (2018) suggest that activities in qualitative data analysis are carried out interactively and continue to completion, so that the data is saturated.

3. Data analysis while in the field

Suggests that the qualitative research process after entering the field begins by assigning an informant as a key "key informant" who is an authoritative informant who is believed to be able to open doors for researchers to enter the research object.

After that the researcher conducted an interview with the informant, and recorded the results of the interview. After the researcher's attention to the object of research and starting to ask descriptive questions and continue with an analysis of the results of the interview (Spradley, 2018).

\section{RESULTS AND DISCUSSION}

This section contains data (in short form), data analysis and interpretation of results. Results can be presented in tables or graphs to clarify the results verbally, because sometimes an illustration is more complete and informative than a narrative display.

This section must answer the problem or research hypothesis that has been formulated previously.

Discussion on Assessment Aspect Questions for Customers Who Want to Financing Home Ownership in Islamic Banks

1) Front Stage

Some people argue that there is an assessment of customers before financing in an Islamic bank, it can be seen from how capable the customer can make financing at an Islamic bank.

2) Back Stage

There are aspects of assessment before the customer does the 5Cs, including Character, 
Capacity, Capital, Collateral, and Condition of Economy. This is shown by the bank to the customer, and this is done by the bank behind the customer in order to avoid problems that will disrupt the syraiah bank.

\section{Discussion on the question of implementing the Murabahah Agreement}

1) Front Stage

Some people argue that in the murabahah contract there are irregularities, such as the murabahah agreement that a bank buys a house from a developer, while the bank cannot do real business. From the results of the interview, there was a bank error regarding the murabahah contract.

2) Back Stage

From the research results, it is found that in practice Islamic banks are only wakalah or representatives of customers and developers, if there is a customer, the bank will buy the house on behalf of the bank and then carry out a sale and purchase agreement between the bank and the customer.

\section{Discussion on Calculation Questions on Home Ownership Financing}

1) Front Stage

Some people think that if in the total amount of installment costs, the installment fees in Islamic banks are higher than conventional banks, then an opinion arises that Islamic banks have usury.

2) Back Stage

From the results of this study, it can be concluded that the price of home financing at Islamic banks is higher if the total is because Islamic banks in their calculations use the flat system, meaning that they do not follow the existing interest rates at that time, if conventional banks use interest rates, the calculations will fluctuate and the financing will feel light if it is at the end of the financing payment period.

\section{Discussion of Questions to Pay Down Payment on Home Ownership Financing}

1) Front Stage

In this case, some people think that in Islamic law it is explained that the down payment that has been given by the customer to the bank, then the house will officially belong to the customer.

2) Back Stage

In research conducted, the down payment given by the customer to the house does not mean that the house will belong to the customer but still belongs to the bank. Advances can be used as collateral that the customer wants to finance home ownership using the Islamic bank. And if the down payment given to the customer already belongs to the customer, then at any time if the customer is unable to make a payment, he will act as he pleases and the bank cannot sue for anything, so the bank will suffer a loss.

\section{Discussion on Questions on Taking Margin from Home Ownership Financing in Islamic Banks}

1) Front Stage

In taking the margin, the bank does not tell the margin that the 
bank gets from the financing of home ownership made by the customer.

2) Back Stage

From the results of the research obtained that the margin withdrawal is submitted by the bank, the important thing is that the bank must comply with the ethics of margin making. So it can be concluded that the taking of the margin has been calculated in advance by the team at the Islamic bank, so that neither the bank nor the customer will be harmed.

\section{Discussion on Fines on Home Ownership Financing in Islamic Banks}

1) Front Stage

The customer explains that there is a fine given by Islamic banks in the event of late payments to Islamic banks.

2) Back Stage

There is a penalty for customers who experience late payments or pay past due date and the bank informs the customer at the time of the contract. That the fines received from this customer are not included by the bank as income, but as income for social purposes. Where to be social, this means to help people who are affected by disaster, as infaq and so on related to social or caring for the people. And in this case the Islamic bank has the responsibility to allocate these funds for social needs.

\section{Discussion of Administrative Costs in the Financing of Home Ownership in Islamic Banks}

1) Front Stage

In practice, Islamic banks have informed customers that there are administrative costs in the use of home ownership financing products.

2) Back Stage

There are administrative fees at Islamic banks, where these costs can be used to pay employee salaries at Islamic banks, for building rental purposes, and so on. In addition, admin fees are allowed because the bank has provided services to customers. Then at Bank BTN Syariah there is an admin fee adjusted from the amount of the financing ceiling at the bank.

\section{Discussion of Problematic Financing Handling Questions on Home Ownership Financing in Islamic Banks}

1) Front Stage

According to the community, the handling of problem financing will be notified by the Islamic bank at the time before the contract occurs to the public.

2) Back Stage

In practice, Islamic banks have handling for customers affected by financing problems and have notified the customer beforehand before the contract has been agreed by both parties. Handling can be in the form of a bank finding out in advance the problems that occur to the customer, then checking whether the customer is still able to continue 
payments. If the customer is unable to continue the payment, the bank will notify you that the house will be taken over or auctioned. If the customer is still able to make payments but cannot pay the price at the beginning of the contract, the bank will restructure or reschedule the payment and contract.

\section{Discussion on Questions, Is There Information Regarding Financing of Home Ownership in Islamic Banks from Islamic Banks}

1) Front Stage

From the results of interviews with customers, that Islamic banks have provided information to customers about existing financing at these Islamic banks.

2) Back Stage

Prior to the contract, banks in practice had provided information regarding the advantages and disadvantages if a customer wanted to finance home ownership, the customer was required to be consistent in his intention to make financing and pay the installments right before the due date.

\section{CONCLUSION AND SUGGESTION}

In practice, Islamic Banks, especially Bank BTN Syariah, KCPS Ciputat, have provided a good appearance in front of the public regarding home ownership financing products.

In dramaturgy theory, Erving Goffman explains that there is a front stage shown by an actor and a back stage that is not shown by an actor to the public. Then the research results show the following:
1. Riba behavior in financing home ownership at Bank BTN Syariah KCPS Ciputat:

a. Front Stage

Some people think that there is still usury in the financing of home ownership in Islamic banks, it can be seen from the total calculation of payments found in Islamic banks that are higher than the total calculations in conventional banks. Then the people assume that under Sharia, if the down payment has been paid, the house will officially belong to the customer, but in reality it still belongs to the bank.

b. Back Stage

In the financing of home ownership in Islamic banks, the calculations used are not in accordance with the prevailing interest rate at that time, meaning that the Islamic bank in the calculation of its financing is flat or does not fluctuate, unlike conventional banks which follow interest rates so that the initial payment will feel heavy but payment at the end will feel light. Then the results of research on the Sharia Supervisory Board explained that the down payment given by the customer was indeed the house not officially owned by the customer, because the down payment was only a guarantee if the customer wanted to continue financing or not. If the payment is in full, the house will officially become the property of the customer.

2. Implementation of the home ownership financing contract system at Bank BTN Sariah KCPS: 
a. Front Stage

Some people argue that in the murabahah contract there are irregularities, such as the murabahah agreement that a bank buys a house from a developer, while the bank cannot do real business. From the results of the interview, there was a bank error regarding the murabahah contract.

b. Back Stage

From the research results, it is found that in practice Islamic banks are only wakalah or representatives of customers and developers, if there is a customer, the bank will buy the house on behalf of the bank and then carry out a sale and purchase agreement between the bank and the customer.

According to the explanation above, it can answer the problems that often arise in the minds of the public regarding financing in Islamic banks. In the financing contained in Islamic banks, Islamic banks are already running their business in

\section{REFERENCES}

Chair, Wasilul. 2014. Riba dalam Perspektif Islam dan Sejarah. Vol 1, No.1.

Fatmasari, Nabila. Analisis Sistem Pembiayaan KPR Bank Konvensional dan Pembiayaan KPRS Bank Syariah (Studi Kasus Bank BTN dan Bank Muamalat).

Heykal, Mohamad. 2014. Analisis Tingkat Pemahaman KPR Syariah Pada Bank Syariah di Indonesia. Vol 5 No.2 hal 519-524. accordance with Islamic law and Islamic banks are running their business in accordance with the applicable National Sharia Council fatwas.

Then Islamic banks have supervision by the Sharia Supervisory Board which aims to ensure that Islamic banks do not deviate from Islamic law in carrying out their business.

Based on the research and conclusions listed above, the researcher has the following suggestions:

1. Bank BTN Syariah remains consistent in running its business in accordance with Islamic law and the existing DSN fatwas

2. Bank BTN syariah continues to develop home ownership financing products and improve management to market home ownership financing products to the public

3. The public is looking for more information about Islamic banks and systems at Islamic banks so that there are no misunderstandings, thus making the image of Islamic banks bad.

Haryamawan, RMA. 1993. Dramaturgi. Bandung: $\quad$ PT Remaja Rosdakarya.Kalsum, Ummu. 2014. "Riba dan Bunga Dalam Bank Syariah (Analisis Hukum dan Dampaknya Terhadap Perekonomian Umat)". Vol. 7 No. 2.

Ifham, Ahmad. 2017. Ini lho KPR Syariah!. Jakarta: PT Gramedia Pustaka Utama.

Ismail. 2016. Perbankan Syariah. Jakarta: Prenadamedia Group.

Karim, A Adiwarman., Sahroni, Oni. 2015. Riba, Gharar, dan Kaidah-Kaidah 
Ekonomi Syariah: Analisis Fikih dan Ekonomi. Jakarta: PT. Raja Grafindo Persada.

Marwini. 2017. Kontroversi Riba dalam Perbankan Konvensional dan Dampaknya Terhadap Perekonomian.

Mahfudz. 2018. Mekanisme Pembayaran KPR iB Berdasarkan Akad Murabahah di Perbankan Syariah. Vol. 4 No. 2.

Man 10 Jakarta. 2015. Langkah-Langkah dalam Penelitian. [Online] Tersedia: http://man10jakarta.sch.id/langkahlangkah-dalam-penelitian-ilmiah/. [17 Desember 2019].

Nasir, Marcela Shindy. Sululing, Siswandi. 2015. Penerapan Akuntansi Murabahah Terhadap Pembiayaan Kredit Pemilikan Rumah Pada Bank Syariah Mandiri Cabang Luwuk. Vol XIX No. 01 hal 109-128.Otoritas Jasa Keuangan. Perbankan Syariah dan Kelembagaannya. [Online] Tersedia: https://www.ojk.go.id/id/kanal/syariah/ tentang-syariah/Pages/PBS-dan-

Kelembagaan.aspx. $\quad[7 \quad$ Desember 2019].

Otoritas Jasa Keuangan. 2013. Peraturan Undang-Undang Nomor 21 Tahun 2008 Tentang Perbankan Syariah.

Pengusaha Muslim. Fatwa DSN-MUIVs. Perbankan Syariah. [Online] Tersedia: https://pengusahamuslim.com/2728fatwa-dsn-mui-1451.html. $[22$ Desember 2019.].

Rochman, Arif. Triasih, Dharu. Abib, Agus Saiful. 2017. "Tinjauan Hukum Islam Terhadap Sistem Transakasi Kredit Pemilikan Rumah (KPR) di Bank Tabungan Negara (BTN Syariah) Semarang”. Vol. 2 No. 1 hal 107-117.

Satria, Rizal Muhammad. Setiani, Tia. 2018. Analisis Perbandingan
Pemberian Kredit Pemilikan Rumah (KPR) pada Bank Konvensional dengan Pembiayaan Murabahah (KPR) pada Bank Syariah (Studi Kasus pada Bank BJB dengan Bank BJB Syariah). Vol 7 No. 3 Hal 167.

Yaya, Rizal., Martawireja, Aji Erlangga., Abdurahim, Ahim. 2016. Akuntansi perbankan syariah. Jakarta: Salemba Empat.

Zuhri, Muh.1966. Riba dalam Al-Qur'an dan masalah perbankan. Jakarta: PT Raja Grafindo Persada. 